\title{
Toxicity of synthetic flavorings, nature identical and artificial, to hematopoietic tissue cells of rodents
}

\author{
I. M. S. Sales ${ }^{a}$, J. M. Silva ${ }^{a}$, E. S. R. Moura ${ }^{a}$, F. D. S. Alves ${ }^{a}$, F. C. C. Silva ${ }^{a, b}$, \\ J. M. C. Sousa ${ }^{a, b}$ and A. P. Peron ${ }^{a, c *}$ \\ ${ }^{a}$ Laboratório de Citogenética e Mutagênese - LaCM, Universidade Federal do Piauí - UFPI, Campus Senador Helvídio \\ Nunes de Barros - CSHNB, Rua Cícero Duarte, 940, Bairro Junco, CEP 64607-670, Picos, PI, Brazil \\ bPrograma de Pós-graduação em Ciências Farmacêuticas - PPGCF, Centro de Ciências da Saúde - CCS, Universidade \\ Federal do Piauí - UFPI, Campus Ministro Petrônio Portella - CMPP, Bairro Ininga, CEP 64049-550, Teresina, PI, Brazil \\ 'Programa de Pós-graduação em Genética e Melhoramento - PPGM, Centro de Ciências Agrárias - CCA, \\ Universidade Federal do Piauí - UFPI, Campus Ministro Petrônio Portella - CMPP, Bairro Ininga, lado ímpar, \\ CEP 64049-550, Teresina, PI, Brazil \\ *e-mail: anapaulaperon@ufpi.edu.br
}

Received: May 27, 2016 - Accepted: November 13, 2016 - Distributed: May 31, 2018

\begin{abstract}
The goal of this study was to analyze cytotoxicity, genotoxicity and mutagenicity to bone marrow cells of mice of nature identical synthetic flavorings, passion fruit and strawberry, and artificial synthetic flavorings, vanilla, chocolate, tutti-frutti and cookie, at doses $0.5 ; 1.0 ; 2.0 ; 5.0$ and $10.0 \mathrm{~mL} / \mathrm{kg}$. The additives were given to the animals by gavage in a single daily application for seven days. Data were subjected to analysis of variance (ANOVA) followed by post Tukey's post hoc test, $\mathrm{p}<0.05$. Animals treated with $2.0 ; 5.0$ and $10.0 \mathrm{~mL} / \mathrm{Kg}$ of flavorings chocolate, strawberry and cookie, and 5.0 and $10.0 \mathrm{~mL} / \mathrm{Kg}$ of flavorings vanilla and passion fruit died on the fifth and sixth day of the experiment, respectively. The doses 0.5 and $1.0 \mathrm{~mL} / \mathrm{Kg}$ of the six additives significantly reduced erythropoiesis in the examined tissue. Also, treatments 0.5 and $1.0 \mathrm{~mL} / \mathrm{Kg}$ of chocolate, and $1.0 \mathrm{~mL} / \mathrm{Kg}$ of strawberry and biscuit induced the formation of micronuclei in the bone marrow erythrocytes, at a significant frequency. Therefore, under the study conditions, the six microingredients analyzed were cytotoxic and genotoxic, and additives strawberry, chocolate and cookie were also mutagenic in at least one of the evaluated doses.
\end{abstract}

Keywords: aroma and flavor adittive, cytotoxicity, genotoxicity, mutagenicity, bone marrow.

\section{Toxicidade de aromatizantes alimentares sintéticos idênticos aos naturais e artificiais a células de tecido hematopoiético de roedores}

\begin{abstract}
Resumo
Os aromatizantes são essenciais para a indústria na confecção de alimentos industrializados. Porém, pouco se sabe sobre o potencial tóxico desses microingredientes alimentares. Dessa forma, objetivou-se neste trabalho analisar, em células de medula óssea de camundongos, a citotoxicidade, genotoxicidade e mutagenicidade de aromatizantes alimentares sintéticos idênticos ao natural, de maracujá e morango, e artificiais, de baunilha, chocolate, tutti-frutti e biscoito, nas doses 0,$5 ; 1,0 ; 2,0 ; 5,0$ e 10,0 mL/Kg. Os aditivos foram administrados aos animais via gavagem em aplicação diária única durante sete dias. Os dados obtidos foram submetidos ao procedimento estatístico ANOVA com pós teste de Tukey, com $\mathrm{p}<0.05$. Os animais tratados com 2,0; 5,0 e $10,0 \mathrm{~mL} / \mathrm{Kg}$ dos aromatizantes de chocolate, morango e biscoito, e 5,0 e 10,0 mL/Kg dos aromatizantes de baunilha e maracujá vieram a óbito no quinto e sexto dia de experimento, respectivamente. As doses 0,5 e $1,0 \mathrm{~mL} / \mathrm{Kg}$ dos seis aditivos reduziram significativamente a eritropoiese do tecido analisado. Ainda, os tratamentos 0,5 e 1,0 mL/kg de chocolate, e 1,0 mL/Kg de morango e biscoito induziram a formação de micronúcleos aos eritrócitos de medula em frequência significante. Portanto, nas condições de estudo estabelecidas, os seis microingredientes analisados foram citotóxico e genotóxicos, e os aditivos de morango, chocolate e biscoito também foram mutagênicos em pelo menos uma das doses avaliadas.
\end{abstract}

Palavras-chave: aditivo de aroma e sabor, citotoxicidade, genotoxicidade, mutagenicidade, medula óssea. 


\section{Introduction}

Globalization and the development of new technologies have caused significant changes in the eating habits of the population, which, in recent decades, has gradually introduced foods rich in chemical additives into the everyday life (Gomes et al., 2013; Moura et al., 2016). Among these substances, also called microingredients, are the flavorings, essential for the food industry for conferring specific sensory properties of taste and smell to processed foods (Xu et al., 2015; Marques et al., 2015). They have a complex formulation, comprising a wide variety of chemical compounds, such as diluents, preservatives, colorants, among others (Brasil, 2007; Koca et al., 2015), and are classified by the food industry into natural flavorings, synthetic nature identical and synthetic artificial.

All over the world, flavoring microingredients are standardized and released for use by food safety agencies Food and Agriculture Organization (FAO) and Flavor and Extract Manufacturers Association (FEMA) (Xu et al., 2015), and, in Brazil, by the National Sanitary Surveillance Agency (ANVISA) through RDC Resolution 2 of January 15 th 2007 (Brasil, 2007). However, none of these regulatory agencies report in detail which compounds and concentrations are present in these substances, and to date also have not defined the Acceptable Daily Intake (ADI) and the tolerable dose limit of flavorings for each food type (Brasil, 2007; Zengin et al., 2011; More et al., 2012; Xu et al., 2015; Marques et al., 2015; Moura et al., 2016). Thus, technical regulations of FAO and FEMA mention the need for conduction of acute toxicological studies of flavorings, especially at the cellular level so as to determine whether or not the need for more detailed research on the toxic effects to organisms (Xu et al., 2015; Marques et al., 2015; Moura et al., 2016).

Cytotoxic and mutagenic activity of genotoxic agents almost always cause significant adverse effects, such as the development of tumors, after long exposure in the body (Almeida et al., 2012; Rothfuss et al., 2011). In this way, it becomes necessary quick, practical and efficient tests to early detect the toxic potential of these agents. The micronucleus test in bone marrow of rodents is extensively used and internationally accepted by regulatory agencies as an essential in vivo genotoxicity assay in the evaluation of mutagenicity of different xenobiotics, representing an important biomarker for the detection of compounds with carcinogenic potential (Almeida et al., 2012; Aissa et al., 2012). This evaluation system also allows for inferring the cytotoxicity of the test substance by reducing the production and maturation of erythropoietic cells (Queiroz et al., 2013).

Given the above, this study aimed to evaluate, through the bone marrow of mice, the cytotoxic, genotoxic and mutagenic potential of flavoring additives, nature identical passion fruit and strawberry flavors, and artificial vanilla, chocolate, tutti-frutti and cookie flavors. These microingredients were chosen for analysis because they are used extensively by the food industry in the production of processed sweet foods.

\section{Material and Methods}

For this study, no dilution was made to set the doses of flavorings, that is, it was tested the toxicity of these additives by directly administering to animals the original solutions in vials of the products. We chose to do it this way because the aroma additives have complex chemical formulation, and so, the concentration and the action of compounds present in these microingredients could be altered if diluted. It is also important to inform that the formulation of any synthetic food flavoring is world standard, according to the Technical Regulation on Flavorings of ANVISA (Brasil, 2007).

Liquid food flavorings, synthetic, passion fruit, strawberry, vanilla, chocolate, tutti-frutti and cookie were obtained from a retailer specialized in national and international marketing of synthetic food additives located in northeastern Brazil. Flavorings tested in the present study were stored in amber bottles with a capacity of $100 \mathrm{~mL}$, and were within the shelf life.

As mentioned previously, to date, there is no IDA established to food flavorings and there is no literature concerning toxicological analysis in animal systems with these substances. Thus, for the assessment of toxicity of the six additives, based on the method proposed by Miller and Tainter (1944), $10 \mathrm{~mL}$ (flavoring)/Kg body weight or $0.1 \mathrm{~mL}$ (flavoring) $/ 10 \mathrm{~g}$ body weight, we set the doses $0.5 ; 1.0 ; 2.0 ; 5.0$ and $10.0 \mathrm{~mL} / \mathrm{Kg}$.

Swiss mice (Mus musculus L.), males and females of three months of age and $50 \mathrm{~g}$ average body weight, were provided by the Central Animal House, Federal University of Piauí (Teresina, Brazil). Mice were housed in plastic cages at a constant temperature of $25 \pm 2{ }^{\circ} \mathrm{C}$ and 12 hour light-dark cycle. The feeding regime was the classic, with standard commercial chow and water provided ad libitum.

Animals were treated according to principles set by the Brazilian College on Animal Experimentation (COBEA) and in accordance with the provisions of the Brazilian law (Brasil, 2008). The experimental protocol of this study was previously approved by the Ethics Committee for Animal Experimentation (CEEA) of the Federal University of Piauí, under the opinion 008/2015.

A total of 07 experimental groups were analyzed: Negative Control Group - untreated animals; Positive Control Group - animals treated with $50 \mathrm{mg} / \mathrm{Kg}$ cyclophosphamide, equivalent to $36.45 \%$ lethal dose; and Treatment groups to analyze each of the six flavorings: Treatment Group 1 - animals treated with the dose of $0.5 \mathrm{~mL} / \mathrm{Kg}$; Treatment Group 2 - animals treated with the dose of $1.0 \mathrm{~mL} / \mathrm{Kg}$; Treatment Group 3 - animals treated with the dose of $2.0 \mathrm{~mL} / \mathrm{Kg}$; Treatment group 4 - animals treated with the dose of $5.0 \mathrm{~mL} / \mathrm{Kg}$; Treatment Group 5 - animals treated with the dose of $10.0 \mathrm{~mL} / \mathrm{Kg}$.

In each experimental group, three mice were randomly selected as to sex. Microingredients were administered via gavage in a single daily application for seven days via syringe for oral administration of small dosages. Mice of the positive control group received cyclophosphamide at 
$50 \mathrm{mg} / \mathrm{Kg}$ i.p., only 24 hours before the sacrifice. On the eighth day, after sacrifice by cervical dislocation, femurs were removed by surgery for bone marrow extraction.

\subsection{Micronucleus test and cytotoxicity to bone marrow cells, slide preparation and analysis}

Bone marrow extracted was inserted into medium for karyotyping and then centrifuged in Falcon tube twice, at 1,000 rpm for 5 minutes. From the resulting suspension, a drop was spread across a slide by smear. After drying, the material in the blades was fixed in PA methanol for 10 minutes, allowed to dry at room temperature, and stained. Blades were stained with Giemsa diluted in phosphate buffer, $\mathrm{pH} 6.8$, at a ratio of $1: 10$, for 15 minutes. After staining, the slides were washed in distilled water and air-dried.

The material was examined with oil immersion microscopy; in which, we assessed the mutagenic potential in 1,000 polychromatic erythrocytes (PCE) per animal to check the frequency of micronucleated cells in accordance with the criteria proposed by Titenko-Holland et al. (1997). To determine the cytotoxicity and genotoxicity, a total of 400 polychromatic erythrocytes (PCE) and normochromatic erythrocytes (ENC) were counted, per animal (200/blade) and the record of PCE frequency was calculated using the formulat: PCE/PCE + NCE. Data obtained from the animal assays were evaluated by ANOVA followed by Tukey's test using STATISTICA 7.0 software, with $\mathrm{p}<0.05$.

\section{Results and Discussion}

Animals treated with doses of 2.0; 5.0 and $10.0 \mathrm{~mL} / \mathrm{Kg}$ of flavorings chocolate, strawberry and cookie, and 5.0 and $10.0 \mathrm{~mL} / \mathrm{Kg}$ of flavorings vanilla and passion fruit died on the fifth and sixth day of the experiment, respectively. It was not possible to determine, under the study conditions, the median lethal dose $\left(\mathrm{LD}_{50}\right)$ for the six evaluated flavorings.

Based on the results listed in Table 1, the six microingredients at the doses 0.5 and $1.0 \mathrm{~mL} / \mathrm{Kg}$, and passion fruit and vanilla additives, in treatment $2.0 \mathrm{~mL} / \mathrm{Kg}$, significantly altered the number of polychromatic or immature cells in the marrow, causing a substantial reduction in erythropoiesis in the studied tissue, proving to be cytotoxic. Doses 0.5 and $1.0 \mathrm{~mL} / \mathrm{Kg}$ of vanilla, chocolate, strawberry and cookie flavorings revealed mutagenic potential for significantly inducing the formation of micronucleated erythrocytes.

The results of cytotoxicity and genotoxicity suggest that the flavorings passion fruit, strawberry, vanilla, chocolate, tutti-frutti and cookie, under the conditions of the proposed analysis, caused reduction of erythropoiesis by promoting derangements in the mitotic spindle, which reduced expressively the frequency of polychromatic or immature cells in the hematopoietic tissue examined. According to Aissa et al. (2012), such disorders in a significant frequency may cause nuclear instability through structural chromosome damage, generating acentric fragments, and/or delay in migration of whole chromosomes for the cell poles during cell division, conditions that cause the formation of micronuclei in the newly formed cells.

The significant presence of micronuclei classifies the substance or compound as a mutagen (Aissa et al., 2012), which was observed for additives strawberry, chocolate and cookie flavors in the present study. According to Almeida et al. (2012), the occurrence of micronuclei, although it is not a carcinogenicity measurement, is often associated with the appearance of cancer, in view of the correlation between the increased frequency of micronucleated cells and detecting cancer in mammals.

Table 1. Cytotoxic, genotoxic and mutagenic potential of food additives passion fruit and vanilla flavors at the doses $0.5 ; 1.0$ and $2.0 \mathrm{~mL} / \mathrm{Kg}$, strawberry, chocolate, tutti-frutti and cookie, at the doses 0.5 and $1.0 \mathrm{~mL} / \mathrm{Kg}$, to femoral bone marrow cells of mice, treated orally with a single daily application, for seven days.

\begin{tabular}{lccc}
\hline \multicolumn{1}{c}{ Group } & Treatment & Cytotoxicity & Mutagenicity \\
\hline Negative Control & Untreated & $1.12 \pm 0.32$ & $3 \pm 2.52$ \\
Positive Control & Cyclophosphamide & $0.52 \pm 0.07^{\mathrm{a}}$ & $15.33 \pm 3.67^{\mathrm{a}}$ \\
Passion Fruit & $0.5 \mathrm{~mL} / \mathrm{Kg}$ & $0.23 \pm 0.10^{\mathrm{a}}$ & $5.66 \pm 3.2$ \\
& $1.0 \mathrm{~mL} / \mathrm{Kg}$ & $0.25 \pm 0.16^{\mathrm{a}}$ & $1.83 \pm 1.50$ \\
& $2.0 \mathrm{~mL} / \mathrm{Kg}$ & $0.40 \pm 0.23^{\mathrm{a}}$ & $2.5 \pm 0.83$ \\
Strawberry & $0.5 \mathrm{~mL} / \mathrm{Kg}$ & $0.57 \pm 0.11^{\mathrm{a}}$ & $13.33 \pm 4.33$ \\
& $1.0 \mathrm{~mL} / \mathrm{Kg}$ & $0.76 \pm 0.09^{\mathrm{a}}$ & $15.50 \pm 4.66^{\mathrm{a}}$ \\
Vanilla & $0.5 \mathrm{~mL} / \mathrm{Kg}$ & $0.28 \pm 0.12^{\mathrm{a}}$ & $2.5 \pm 0.83$ \\
& $1.0 \mathrm{~mL} / \mathrm{Kg}$ & $0.45 \pm 0.04^{\mathrm{a}}$ & $2.50 \pm 0.83$ \\
Chocolate & $2.0 \mathrm{~mL} / \mathrm{Kg}$ & $0.43 \pm 0.41^{\mathrm{a}}$ & $12.83 \pm 4.77$ \\
& $0.5 \mathrm{~mL} / \mathrm{Kg}$ & $0.64 \pm 0.07^{\mathrm{a}}$ & $18.16 \pm 6.23^{\mathrm{a}}$ \\
Tutti-frutti & $1.0 \mathrm{~mL} / \mathrm{Kg}$ & $0.69 \pm 0.08^{\mathrm{a}}$ & $14.66 \pm 5.78^{\mathrm{a}}$ \\
& $0.5 \mathrm{~mL} / \mathrm{Kg}$ & $0.44 \pm 0.11^{\mathrm{a}}$ & $4.8 \pm 1.77$ \\
Cookie & $1.0 \mathrm{~mL} / \mathrm{Kg}$ & $0.55 \pm 0.10^{\mathrm{a}}$ & $3.1 \pm 1.88$ \\
& $0.5 \mathrm{~mL} / \mathrm{Kg}$ & $0.50 \pm 0.08^{\mathrm{a}}$ & $10.0 \pm 3.4$ \\
& $1.0 \mathrm{~mL} / \mathrm{Kg}$ & $0.73 \pm 0.02^{\mathrm{a}}$ & $29.50 \pm 1.5^{\mathrm{a}}$
\end{tabular}

ANOVA followed by Tukey's test; ${ }^{a}$ significant compared to the negative control, considering $\mathrm{p}<0.05$. 
Confirming the our findings, Nunes et al. (2017) and Marques et al. (2015) found that, with the Allium cepa system, additives passion fruit, vanilla, chocolate and strawberry flavors promoted a significant reduction of cell division, mitotic spindle changes, like anaphase and telophase bridges and micronuclei in root cells, highlighting the significant cytotoxic, genotoxic and mutagenic potential. Still, the literature contains studies showing the toxicity at the cellular level of chemical constituents with diluent and preservative roles, according to Resolution RDC Number 2 of January $15^{\text {th }}, 2007$, in the basic formulation of flavorings, which corroborate the toxicity at the cellular level observed in this study.

Among the diluents present in flavoring, stand out benzoic alcohol and diacetyl (2,3-butadione), which promoted significant changes in the mitotic spindle and cell division to human peripheral blood cells (Demir et al., 2010) and significant damage to the chromosome 11 loci of rodents, causing loss of expression of genes essential for cell division (Whittaker et al., 2008), respectively. In addition, More et al. (2012) reported that the diluent diacetyl had the potential to replace thymine with guanine in euchromatin regions, resulting in the disruption of hydrogen and disulfide bonds in the tertiary structure of enzymes important for mitosis. Among the preservatives, potassium benzoate, sodium benzoate, potassium nitrate, are cytotoxic and genotoxic to normal cells of human peripheral blood (Mpountoukas et al., 2010; Zengin et al., 2011), boric acid, citric acid, potassium citrate and sodium citrate are cytotoxic and genotoxic to root meristem cells of $A$. cepa, as they caused a significant decline in the cell division rate of the examined tissue (Türkoğlu, 2007).

It is important to mention that despite the lack of information in the scientific literature on systemic toxicity, and especially at the cellular level of flavorings in general, ANVISA, though not mentioning which studies, concentrations and compounds, or which flavoring have determined such a conclusion, stated that the flavoring microingredients, when consumed in high doses, cause annoying and narcotic actions to the organism, causing toxicity to the digestive tract when consumed chronically and indiscriminately (Brasil, 1999, 2007). Moreover, Salinas (2002) and Polonio and Peres (2009) claimed that the use of flavorings in low doses does not pose risk to human health, however, at high dose levels, can cause annoying and narcotic actions and chronic cellular toxicity in the long term. Similarly, these authors do not specify which doses or concentrations of these additives are considered high or low. They also do not discriminate which flavorings nor the test organisms used to obtain this information.

The additives passion fruit, strawberry, vanilla, chocolate, tutti-frutti and cookie flavors, under the conditions set in this study, were highly toxic. The results obtained in this study and those already available in the scientific literature on the cellular toxicity of some constituents of the chemical composition of flavorings show that although the use of flavoring additives is allowed by FAO, FEMA and ANVISA, there is an urgent need for clarification, through more detailed studies in the medium and long term, in different test systems, doses and exposure time, as to the toxicity of these substances. Although preliminary, our results indicate the need to set, as by high performance liquid chromatography, the chemical composition of flavorings in general, so as to consistently determine the toxicity of these additives property and ensure the safety of consumers.

\section{References}

AISSA, A.F., BIANCHI, M.L.P., RIBEIRO, J.C., HERNANDES, L.C., FARIA, A.F., MERCADANTE, A.Z. and ANTUNES, L.M.G., 2012. Comparative study of $\beta$-carotene and microencapsulated $\beta$-carotene: evaluation of their genotoxic and antigenotoxic effects. Food and Chemical Toxicology, vol. 50, no. 5, pp. 1418-1424. PMid:22386811. http://dx.doi.org/10.1016/j.fct.2012.02.030.

ALMEIDA, M.R., DARIN, J.D., HERNANDES, L.C., AISSA, A.F., CHISTÉ, R.C., MERCADANTE, A.Z., ANTUNES, L.M. and BIANCHI, M.L., 2012. Antigenotoxic effects of piquiá (Caryocar villosum) in multiple rat organs. Plant Foods for Human Nutrition, vol. 67, no. 2, pp. 171-177. PMid:22562095. http://dx.doi.org/10.1007/s11130-012-0291-3.

BRASIL. Ministério da Saúde. Agência Nacional de Vigilância Sanitária-ANVISA, 1999 [viewed 13 April 2015]. Resolução $n^{\circ}$ 104, de 14 de maio de 1999. Aprova o Regulamento técnico sobre aditivos aromatizantes/aroma. Diário Oficial da República Federativa do Brasil [online], Brasília. Available from: http://www.engetecno. com.br/port/legislacao/norqual_aditivos_aromatizantes.htm.

BRASIL. Ministério da Saúde. Agência Nacional de Vigilância Sanitária - ANVISA, 2007 [viewed 12 April 2015]. Resolução da Diretoria Colegiada RDC $n^{\circ}$ 05, de 15 de janeiro de 2007. Diário Oficial da República Federativa do Brasil [online], Brasília. Available from: http://www.anvisa.gov.br/legis/resol/2007/ rdc/02_170107rdc.pdf.

BRASIL, 2008 [viewed 7 June 2017]. Lei no 11.794, de 8 de Outubro de 2008. Regulamenta o inciso VII do $\$ 1$ o do art. 225 da Constituição Federal, estabelecendo procedimentos para o uso científico de animais; revoga a Lei no 6.638, de 8 de maio de 1979. Diário Oficial da República Federativa do Brasil [online], Brasília, 9 out. p. 1. Available from: http://www.planalto.gov.br/ ccivil_03/_ato2007-2010/2008/lei/111794.htm.

DEMIR, E., KOCAOGLU, S. and KAYA, B., 2010. Assessment genotoxic effects of benzyl derivatives by comet assay. Food and Chemical Toxicology, vol. 48, no. 5, pp. 1239-1242. PMid:20170703. http://dx.doi.org/10.1016/j.fct.2010.02.016.

GOMES, K.M.S., OLIVEIRA, M.V.G.A., CARVALHO, F.R.S., MENEZES, C.C. and PERON, A.P., 2013. Citotoxicity of food dyes sunset yellow (E-110), bordeax red (E-123), and tatrazine yellow (E-102) on Allium cepa L. root meristematic cells. Food Science and Technology, vol. 33, no. 1, pp. 218-223. http://dx.doi. org/10.1590/S0101-20612013005000012.

KOCA, N., ERBAY, Z. and KAYMAK-ERTEKIN, F., 2015. Effects of spray-drying conditions on the chemical, physical, and sensory properties of cheese powder. Journal of Dairy Science, vol. 98, no. 5, pp. 2934-2943. PMid:25771045. http://dx.doi. org/10.3168/jds.2014-9111.

MARQUES, G.S., SILVA, S.I.O., SOUSA, J.M.C., FERREIRA, P.M.P. and PERON, A.P., 2015. Cytotoxicity and mutagenic potential of liquid synthetic food flavoring evaluated individually and in association. Food Science and Technology, vol. 35, no. 1, pp. 183-188. http://dx.doi.org/10.1590/1678-457X.6596. 
MILLER, L.C. and TAINTER, M.L., 1944. Estimation of the ED50 and Its Error by Means of Logarithmic-Probit Graph Paper. Proceedings of the Society for Experimental Biology and Medicine, vol. 57, no. 2, pp. 261-264. http://dx.doi.org/10.3181/00379727$57-14776$.

MORE, S.S., RAZA, A. and VINCE, R., 2012. The butter flavorant, diacetyl, forms a covalent adduct with 2-deoxyguanosine, uncoils DNA, and leads to cell death. Journal of Agricultural and Food Chemistry, vol. 60, no. 12, pp. 3311-3317. PMid:22385266. http:// dx.doi.org/10.1021/jf300180e.

MOURA, A.G., SANTANA, G.M., FERREIRA, P.M.P., SOUSA, J.M.C. and PERON, A.P., 2016. Cytotoxicity of cheese and cheddar cheese food flavorings on Allim cepa $\mathrm{L}$ root meristems. Brazilian Journal of Biology = Revista Brasileira de Biologia, vol. 76, no. 2, pp. 439-443. PMid:26959949. http://dx.doi. org/10.1590/1519-6984.20514.

MPOUNTOUKAS, P., PANTAZAKI, A., KOSTARELI, E., CHRistodoulou, P., KARELI, D., POLILIOU, S., MOURELATOS, C., LAMBROPOULOU, V. and LIALIARIS, T., 2010. Cytogenetic evaluation and DNA interaction studies of the food colorants amaranth, erythrosine and tartrazine. Food and Chemical Toxicology, vol. 48, no. 10, pp. 2934-2944. PMid:20667460. http://dx.doi.org/10.1016/j.fct.2010.07.030.

NUNES, R.D.M., SALES, I.M.S., SILVA, S.I.O., SOUSA, J.M.C. and PERON, A.P., 2017. Antiproliferative and genotoxic effects of nature identical and artificial synthetic food additives of aroma and flavor. Brazilian Journal of Biology = Revista Brasileira de Biologia, vol. 77, no. 1, pp. 150-154. http://dx.doi. org/10.1590/1519-6984.12115.

POLÔNIO, M.L.T. and PERES, F., 2009. Consumo de aditivos alimentares e efeitos à saúde: desafios para a saúde pública brasileira. Cadernos de Saúde Pública, vol. 25, no. 8, pp. 1653-1666. PMid:19649407. http://dx.doi.org/10.1590/S0102$311 \mathrm{X} 2009000800002$.

QUEIROZ, F.M.D., MATIAS, K.W.D.O., CUNHA, M.M.F.D. and SCHWARZ, A., 2013. Evaluation of (anti) genotoxic activities of Phyllanthus niruri L. in rat bone marrow using the micronucleus test. Brazilian Journal of Pharmaceutical Sciences, vol. 49, no. 1, pp. 135-148. http://dx.doi.org/10.1590/S1984-82502013000100015.
ROTHFUSS, A., HONMA, M., CZICH, A., AARDEMA, M.J., BURLINSON, B., GALLOWAY, S., HAMADA, S., KIRKLAND, D., HEFLICH, R.H., HOWE, J., NAKAJIMA, M., O'DONOVAN, M., PLAPPERT-HELBIG, U., PRIESTLEY, C., RECIO, L., SCHULER, M., UNO, Y. and MARTUS, H.J., 2011. Improvement of in vivo genotoxicity assessment: combination of acute tests and integration into standard toxicity testing. Mutation Research, vol. 723, no. 2, pp. 108-120. PMid:21182982. http:// dx.doi.org/10.1016/j.mrgentox.2010.12.005.

SALINAS, R.D., 2002. Alimentos e nutrição: introdução à bromatologia. Porto Alegre: Artmed. 278 p.

TITENKO-HOLLAND, N., WINDHAM, P., KOLACHANA, F., REINISCH, S., PARVATHAM, A.M., OSORIO, M.T. and SMITH, M.T., 1997. Genotoxicity of malathion in human lymphocytes assessed using the micronucleus assay in vitro and in vivo: a study of malathion-exposed workers. Mutation Research, vol. 388, no. 1, pp. 85-95. PMid:9025795. http://dx.doi.org/10.1016/ S1383-5718(96)00140-4.

TÜRKOĞLU, Ş., 2007. Genotoxicity of five food preservatives tested on root tips of Allium cepa L. Mutation Research, vol. 626, no. 1-2, pp. 4-14. PMid:17005441. http://dx.doi.org/10.1016/j. mrgentox.2006.07.006.

WHITTAKER, P., CLARKE, J.J., SAN, R.H., BEGLEY, T.H. and DUNKEL, V.C., 2008. Evaluation of the butter flavoring chemical diacetyl and a fluorochemical paper additive for mutagenicity and toxicity using the mammalian cell gene mutation assay in L5178Y mouse lymphoma cells. Food and Chemical Toxicology, vol. 46, no. 8, pp. 2928-2933. PMid:18585428. http://dx.doi. org/10.1016/j.fct.2008.06.001.

XU, Z., GU, C., WANG, K., JU, J., WANG, H., RUAN, K. and FENG, Y., 2015. Arctigenic acid, the key substance responsible for the hypoglycemic activity of Fructus Arctii. Phytomedicine, vol. 22, no. 1, pp. 128-137. PMid:25636881. http://dx.doi. org/10.1016/j.phymed.2014.11.006.

ZENGIN, N., YÜZBAŞIOĞLU, D., UNAL, F., YILMAZ, S. and AKSOY, H., 2011. The evaluation of the genotoxicity of two food preservatives: sodium benzoate and potassium benzoate. Food and Chemical Toxicology, vol. 49, no. 4, pp. 763-769. PMid:21130826. http://dx.doi.org/10.1016/j.fct.2010.11.040. 